\title{
Specialized roles for cysteine cathepsins in health and disease
}

\author{
Jochen Reiser, ${ }^{1}$ Brian Adair, ${ }^{2}$ and Thomas Reinheckel ${ }^{3,4}$
}

${ }^{1}$ Department of Medicine, Leonard Miller School of Medicine, University of Miami, Miami, Florida, USA. ${ }^{2}$ Harvard Medical School and Department of Medicine, Massachusetts General Hospital, Charlestown, Massachusetts, USA. ${ }^{3}$ nstitute of Molecular Medicine and Cell Research,

Albert-Ludwigs-University, Freiburg, Germany. ${ }^{4}$ Center for Biological Signaling Studies (BIOSS), Albert-Ludwigs-University, Freiburg, Germany.

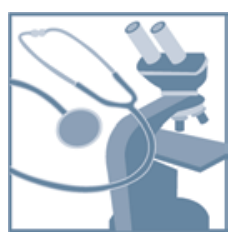

Cathepsins were originally identified as proteases that act in the lysosome. Recent work has uncovered nontraditional roles for cathepsins in the extracellular space as well as in the cytosol and nucleus. There is strong evidence that subspecialized and compartmentalized cathepsins participate in many physiologic and pathophysiologic cellular processes, in which they can act as both digestive and regulatory proteases. In this review, we discuss the transcriptional and translational control of cathepsin expression, the regulation of intracellular sorting of cathepsins, and the structural basis of cathepsin activation and inhibition. In particular, we highlight the emerging roles of various cathepsin forms in disease, particularly those of the cardiac and renal systems.

The maintenance of a healthy organism largely relies upon controlled biosynthesis, maturation, function, and terminal breakdown of proteins. Proteolytic enzymes contribute to these processes by irreversibly cleaving peptide bonds. This can result in destruction of the substrate protein, its maturation, or modulation of the biological activities of the cleavage products. To accomplish the multitude of selective and well-controlled proteolytic events that keep us healthy, the human genome encodes more than 550 proteases and more than 200 endogenous protease inhibitors $(1,2)$.

The so-called "catheptic activity" (derived from the Greek word kathépsein, meaning to digest or to boil down) was first described in the gastric juice during the 1920s (3). Today, cathepsins are classified based on their structure and catalytic type into serine (cathepsins A and G), aspartic (cathepsins D and E), and cysteine cathepsins (Figure 1 and Sidebar 1). The latter constitutes the largest cathepsin family, with 11 proteases in humans referred to as clan CA, family C1a: cathepsins B, C (also known as cathepsin J and dipeptidyl-peptidase 1 ), F, H, K (also known as cathepsin O2), L, O, S, W, V (also known as cathepsin L2), and Z (also known as cathepsin $X$ and cathepsin P) (4). In general, the cysteine cathepsins are stable in acidic cellular compartments, i.e., in lysosomes and endosomes, and capable of efficiently cleaving a wide variety of substrates. Despite this, during the past decade, important and specific functions of cathepsins have been discovered to occur extracellularly and in other locations inside cells, such as secretory vesicles $(5,6)$, the cytosol (7-9), and the nucleus $(10,11)$. When studying the function of cathepsins, one needs to consider species differences between humans and mice (Table 1 and Sidebar 2).

Novel insight into cathepsin function was made possible by various novel genomic, proteomic, and imaging tools as well as the generation and in-depth analysis of knockout and transgenic mice (12). These studies established that cathepsins are not simply redundant, homeostatic enzymes involved in the turnover of proteins delivered to the lysosome by endocytosis or autophagocytosis but are critically involved in the proteolytic processing of

Authorship note: Jochen Reiser, Brian Adair, and Thomas Reinheckel contributed equally to this work.

Conflict of interest: The authors have declared that no conflict of interest exists. Citation for this article: J Clin Invest. 2010;120(10):3421-3431. doi:10.1172/JCI42918. specific substrates. Thus, cathepsins contribute to distinct physiologic processes, such as antigen presentation in the immune system (13), collagen turnover in bone and cartilage $(14,15)$, and neuropeptide and hormone processing $(16,17)$. Various diseases or phenotypes develop when cathepsins are lost in humans or mice, respectively (Tables 2 and 3 ). In addition, ectopic or excessive expression and activity of cathepsins promotes the development of several common diseases in humans and mice, including cancer and arthritis (Table 3).

The roles of cathepsins in many physiologic and disease processes have been covered by recent comprehensive reviews (17-20). Here, we focus on the recently discovered roles of cathepsins in organ diseases, with a special emphasis on the ubiquitously expressed cysteine endopeptidase cathepsin L. In particular, we discuss how the different functions of a cysteine cathepsin depend on the cell type in which it is expressed and the cellular compartment in which the protease is localized. We address the homeostatic function of cathepsin $\mathrm{L}$ in the heart and its potential role in cardiac regeneration, the reciprocal processing function of cathepsins B and $\mathrm{L}$ in ectopic trypsinogen activation during the onset of acute pancreatitis, and the emerging roles of cytosolic and nuclear cathepsin $\mathrm{L}$ variants in proteinuric kidney disease and stem cell physiology, respectively.

\section{A primer on cathepsin biology}

Cathepsin L transcription and translation. Substantial work has been done to analyze the promoter regions of the human cathepsin $\mathrm{L}$ gene (CTSL) promoter as well as to understand the regulation of different splice variants within the $5^{\prime}$ untranslated region of the transcript $(21,22)$. Of note, one of the splice variants contains a functional internal ribosomal entry site that enables ongoing translation of human cathepsin L under stress conditions, and hypoxia can shut down cap-dependent translation initiation (23). More recent work has focused on the regulation of cathepsin $\mathrm{L}$ alternative translation. According to the presence of different forms of cathepsin L in distinct subcellular and extracellular compartments, cathepsin $\mathrm{L}$ proteins can be initiated from downstream AUG sites (10), omitting the signal peptide that is normally present at the $\mathrm{N}$ terminus of lysosomal cathepsin $\mathrm{L}$ that routes the protein to the ER during its synthesis (Figure 2) (10, 24-26). 


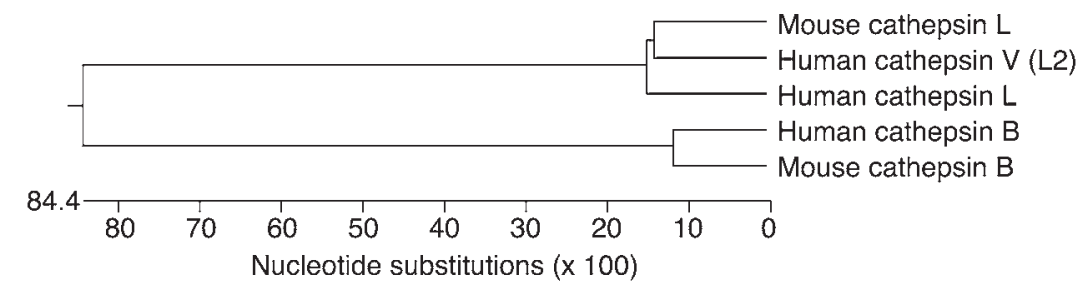

Figure 1

Phylogeny and nomenclature of cathepsins. Phylogenic tree of mouse and human cathepsin proenzymes. Mouse cathepsin L, human cathepsin V, and human cathepsin L are compared with each other and with human and mouse cathepsin B in order to demonstrate the phylogenic distance to other prototypic members of the cysteine cathepsin family.

Cathepsin biosynthesis, processing, and trafficking. As secreted proteins, cathepsins are synthesized with an $\mathrm{N}$-terminal signal peptide that targets the protein to the lumen of the ER (Figure 2). The signal peptide is cotranslationally cleaved and N-linked glycosylation occurs within the ER. Similar to other proteases, cysteine cathepsins are synthesized as inactive proenzymes and require proteolytic processing for activity. The immature protein possesses an $\mathrm{N}$-terminal proregion, which is removed to activate the enzyme, suggesting that the proregion acts as an autoinhibitor. Indeed, synthetic peptides corresponding to proregions do function as specific inhibitors of the parent cathepsin in the case of cathepsin L and cathepsin-like cysteine proteases $(27,28)$. The understanding of the nature of cathepsin propeptide inhibition has been advanced by the structural determination of a number of proenzyme forms of cathepsins, including cathepsins B $(29,30), \mathrm{L}(29), \mathrm{K}(31,32), \mathrm{X}(33)$, and S (34). The structures are broadly similar, with a small "mini-domain" at the $\mathrm{N}$ terminus, which forms a small compact structure, and an extended peptide, which is bound over the active site cleft, occluding it. The inhibitory peptide is not cleaved, as it is held in an inverse, nonproductive orientation over the active site. The folded mini- domain interacts noncovalently with the enzyme to tether the inhibitory peptide over the active site at one end. The tether at the other end is provided by the peptide bond, connecting the enzyme and proregion. Binding within the active site is noncovalent, with the exception of cathepsin $\mathrm{X}$, which has a disulfide bond between a cysteine in the proregion and the active site cysteine (33). In addition to its role in autoinhibition, the $\mathrm{N}$-terminal proregion of cathepsin L appears to be necessary for the correct folding of the protein (35), a finding that is also true for papain (36). Mutations destabilizing the interface between the helices prevent correct folding of the protein $(37,38)$. Folding of the proregion may precede folding of the full protein, thereby providing a scaffold that then directs the folding of the remaining domains. The full structure would be stabilized by the formation of disulfide bonds that prevent unfolding once the proregion has been removed (Figure 2).

Initial glycosylation generates high mannose glycans within the ER. Cathepsins destined for the lysosome are further processed in the Golgi apparatus by modification of mannose residues to mannose-6-phosphate (m6p). For cathepsin D, recognition of the cathepsin by the initial enzyme in $\mathrm{m} 6 \mathrm{p}$ formation requires interactions with surface loops in the structure (39). Two to three lysine residues separated by $34 \AA$ appear to be critical in the recognition motif (40). Modified cathepsins bind to the $\mathrm{m} 6 \mathrm{p}$ receptor for targeting to the lysosome. Upon acidification in late endosomes, cathepsins become active and begin proteolytic processing, with cleavage within the proregion allowing proregion dissociation from the enzyme. This process may occur autocatalytically for both cathepsin B (41) and cathepsin L (42). Due to the distance between the active site and the identified cleavage sites, the process is believed to be intermolecular rather than intramolecular (42).

\section{Sidebar 1}

\section{Structural features of cathepsins}

The name cathepsin is used to designate a diverse number of intracellular acidic proteases, including serine proteases (cathepsins A and $\mathrm{G}$ ), aspartic proteases (cathepsin D and E), and the more numerous cysteine proteases (Figure 1). Based on their primary and tertiary structures, the cysteine cathepsins are members of the clan CA, C1a family of cysteine peptidases. Historically, cysteine cathepsins have been termed papain-like proteases, because they resemble the overall fold of papain, the major protease of the papaya fruit (reviewed in refs. 30 and 108). The mature proteins are generally small (20-30 kDa) and mostly monomeric, with the exception of tetrameric cathepsin C, which contains a C-terminal extension for assembly (109). Posttranslational processing generally results in cleavage of the enzyme into disulfide-linked heavy and light chains (110). Members of the cysteine cathepsin family papain superfamily are composed of two folding domains, comparable in size, divided by a solvent-accessible cleft, containing the enzyme active site. The cleft between the two domains serves as a binding site for the target polypeptide chain of the protein substrate in a generally extended conformation. The extended binding site allows some sequence specificity for different cathepsins. Thus, while the structurally similar cathepsins L, K, and S have similar binding sites and specificities, cathepsin L favors aromatic residues, particularly Phe, at the second position before the cleaved bond, while cathepsins $\mathrm{K}$ and $\mathrm{S}$ will take any hydrophobic residue. Cathepsin $\mathrm{K}$ is unusual in accepting a proline at this position, allowing it to cleave collagen (111). The active site cysteine is part of a conserved "catalytic triad" formed by the cysteine pairing with a histidine, which in turn is paired with an asparagine. The configuration is similar to what is seen in serine proteases and is believed to function by allowing the formation of a thiolate-imidazolium ion pair between the cysteine and the histidine side chains. The thiolate ion from the cysteine subsequently performs a nucleophilic attack on the peptide carbonyl carbon. 


\section{Table 1}

Summary of nomenclature of human and mouse cathepsins $L$ and $V$, together with genomic localization, expression pattern, and some examples of substrate specificity

\begin{tabular}{|c|c|c|c|}
\hline Cathepsin & Symbols ${ }^{A}$ and alleles & Genomic locus & Expression \\
\hline Human cathepsin L & $\frac{C T S L}{C A T L}, \frac{C T S L 1}{M E P}$ & $\begin{array}{l}9 q 21 / 22 \text { (no synteny } \\
\text { in mouse genome) }\end{array}$ & $\begin{array}{c}\text { ubiquitous, expression levels } \\
\text { vary among cell types }\end{array}$ \\
\hline Human cathepsin V & $\frac{\text { CTSV }}{\text { CATL2, CTSU }}, \frac{\text { CTSL2 }}{\text { CTS }}$ & $\begin{array}{l}\text { 9q22.2 (syntenic to mouse } \\
\text { chromosome } 13 ; 30.0 \mathrm{cM} \text {, } \\
\text { i.e., the Cts/locus) }\end{array}$ & $\begin{array}{l}\text { restricted to macrophages, } \\
\text { thymus, testis, cornea, } \\
\text { keratinocytes, some } \\
\text { cancer cell types }\end{array}$ \\
\hline Mouse cathepsin L & $\begin{array}{c}\text { Ctsl, Cts/1, MEP, } \\
n k t, f s\end{array}$ & $\begin{array}{l}\text { Chromosome } 13 ; 30.0 \mathrm{cM} \\
\text { (syntenic to human chromosome } \\
9 q 22.2, \text { i.e., the CTSVIocus) }\end{array}$ & $\begin{array}{c}\text { ubiquitous, expression levels } \\
\text { vary among cell types }\end{array}$ \\
\hline
\end{tabular}

\author{
Substrate specificity \\ cleaves z-PheArg-AMCB; does not \\ cleave elastin; does not generate \\ angiostatin-like peptides \\ from plasminogen \\ cleaves z-PheArg-AMCB; cleaves \\ elastin; generates angiostatin-like \\ peptides from plasminogen
}

cleaves z-PheArg-AMCB; cleaves elastin

ASymbols in common use are underlined. BThe fluorogenic peptide z-PheArg-AMC is frequently used for determination of cathepsin $L$ activities. These assays require inhibition of cathepsin B by a specific inhibitor such as CA074.

This results in an active, single chain form of the protein. Upon arrival at the lysosome, further processing cleaves the protein into two chains. Active cathepsins may also be recruited from late endosomes or lysosomes for secretion into the extracellular space via $\mathrm{Ca}^{2+}$-mediated fusion of these organelles with the plasma membrane $(43,44)$. In addition, a minor population of cathepsins (approximately 5\%) does not travel to the lysosome but is instead secreted as a proenzyme. Furthermore, alternative splicing and exon skipping can lead to cathepsin forms that lack the signal peptide, and these can subsequently localize to the nucleus and mitochondrial matrix (Figure 3) $(21,45)$. Recent data suggest that truncated forms of cathepsin $\mathrm{L}$ are important in regulating the cytoskeleton of kidney podocytes $(7,8)$, whereas others have described mature cathepsin L outside lysosomes, e.g., during histone processing in embryonic stem cells (25). These cathepsin
$\mathrm{L}$ variants have been previously shown to arise by translation from an alternate downstream AUG site (10) and to be located in the nucleus of fibroblasts, in which they can cleave the transcription factor cut-like homeobox 1 (Cux1) (10). Cathepsin L also processes histone $\mathrm{H} 3$ during mouse embryonic stem cell differentiation (25). Although conventional cathepsin $L$ cleaves various proteins very efficiently, due to the denaturing conditions and low $\mathrm{pH}$ of the lysosome, cytosolic and nuclear cathepsin L exhibit remarkable substrate specificity that allows a very specific enzymatic activity at cytosolic or nuclear $\mathrm{pH}$ (46). So far, two substrates of cytosolic cathepsin $\mathrm{L}$ have been described in podocytes: dynamin (7) and synaptopodin (8). In addition, CD2-associated protein (CD2AP) in podocytes is protected from puromycin-induced degradation in the absence of cathepsin L, suggesting the possibility that CD2AP is an additional cathepsin L substrate (9).

\section{Sidebar 2}

\section{Cysteine cathepsins in humans and mice}

Most of the human cysteine cathepsins possess a highly homologous mouse counterpart, which makes the generation and analysis of cathepsin-knockout mice a relatively straightforward approach to understanding the in vivo functions of these proteases. However, because of a series of tandem duplications of an ancestral cathepsin $\mathrm{L}$ gene, the mouse genome, but not that of the human, encodes an additional set of 8 closely related cysteine cathepsins that are all exclusively expressed in the placenta of mice (112). It is even more striking that in human phylogeny cathepsin L evolved into two closely related proteases, namely the "classic" human cathepsin L and human cathepsin V (Table 1 and Figure 1). All three enzymes - mouse cathepsin L, human cathepsin $\mathrm{L}$, and human cathepsin $\mathrm{V}$ - are highly homologous, with about $75 \%$ amino acid identities. Nevertheless, the three proteases vary in their expression pattern and some (but not all) biochemical properties (Table 1). Consequently, commonly used biochemical assays for activity measurement do not distinguish between human cathepsins $\mathrm{L}$ and $\mathrm{V}$, and a serious note of caution is required for conclusions on human cathepsin $\mathrm{L}$ drawn from analyses of $\mathrm{Cts}^{-/}$- mice. Inhibitors selective for cathepsin $\mathrm{L}$ and $\mathrm{V}$ are just emerging (113) and will prove useful in determining their individuals functions. Furthermore, the search for disease associations with expression or genetic polymorphisms of cathepsins (114-116), together with functional analysis of human cells and mouse experiments combining gene knockouts with transgenic expression of the human proteases, have already provided valuable insights into the specific in vivo functions of human cathepsins $L$ and $V(74,117,118)$. In summary, the complex phylogeny, the widespread expression of cathepsin L-like enzymes, and the multiple phenotypes of the gene knockout mice highlight the great importance of the cathepsin L-like proteases in physiology and disease processes. Defining specific in vivo functions for human cathepsins $\mathrm{L}$ and $\mathrm{V}$ and testing their individual potential as diagnostic markers or drug targets represents a considerable challenge for further investigations. 


\section{Table 2}

Human syndromes caused by inherited cysteine cathepsin mutations

\author{
Inherited syndrome \\ Papillon-Lefèvre and \\ Haim-Munk syndromes

\section{Cysteine cathepsin} \\ Cathepsin C \\ loss-of-function mutations
}

Pycnodysostosis
Cathepsin $\mathrm{K}$

loss-of-function mutations
Description

Refs.

Hyperkeratosis palmoplantaris with periodontosis in humans.

The severe periodontitis causes early loss of primary and permanent teeth, due to destruction of alveolar bone. Ctsc-null mice show impaired activation of granzymes and other immune cell serine proteases. This may be the cause for dysregulation of localized polymorphonuclear leucocyte response in the inflamed periodontal tissues of patients with Papillon-Lefèvre/Haim-Munk disease.

Pycnodysostosis is characterized by osteopetrosis, caused by impaired degradation of collagen I in the bone matrix in humans, with an identical phenotype in Cstk-null mice. Ctsk inhibitors are in trials for slowing turnover of bone in osteoporosis.
119,120

$121-124$

\section{Opposing roles of cathepsins $B$ and $L$ in acute pancreatitis}

Physiological activation of digestive proteases. The acinar cells of the exocrine pancreas produce and secrete a wide variety of potent proteolytic enzymes essential for intestinal digestion of nutrient proteins. However, these digestive enzymes are potentially harmful. Therefore, these proteases are produced as precursors (i.e., zymogens) within pancreatic acinar cells and are only activated in the duodenum. The key step in this activation process is the conversion of inactive trypsinogen to active trypsin by limited proteolysis by enteropeptidase, a highly selective trypsinogen-cleaving protease located at the luminal site of duodenal cells (26). The proteolytically active trypsin initiates an activation cascade of proteolytic enzymes within the duodenum, thereby ensuring the high proteolytic capacity needed for food digestion (26).

Cathepsin B: a major trypsin activator in acute pancreatitis. Because of the vital role of trypsin in protease activation, the ectopic intrapancreatic cleavage of trypsinogen to proteolytically active trypsin has long been considered as a key event in the pathogenesis of acute and chronic pancreatitis (47). The most direct evidence for this pathogenic principle comes from recent work on hereditary chronic pancreatitis: most affected families have heritable mutations that either increase the autoactivation of trypsinogen or impair the inhibition/degradation of active trypsin within pancreatic acinar cells (48). Yet, cathepsin mutations have not been found in hereditary pancreatitis. However, cathepsin B has long been considered a promising candidate for the trypsinogen-activating protease in pancreatic acinar cells. Support for this notion stems from in vitro experiments showing that cathepsin B can remove the $\mathrm{N}$-terminal hexapeptide, the so called "trypsinogen-activation peptide", from the human, rodent, and bovine trypsinogen zymogens. Notably, this cleavage mimics that of the physiological trypsinogen activator enteropeptidase $(49,50)$. The isoleucine residue that is exposed and represents the $\mathrm{N}$ terminus of trypsin interacts via its free amino group with the side-chain carboxy group of asparagine 194 (chymotrypsin numbering), thereby enabling and stabilizing the proteolytic active conformation of trypsin (51). The functional relevance of cathepsin B for trypsinogen activation in acute pancreatitis has been analyzed in various rodent models. In these studies, both genetic deficiency for cathepsin B and treatment of animals with a cathepsin B inhibitor resulted in reduced trypsin activity and amelioration of pancreatitis (52-54).
Cathepsin L: keeping trypsin in check. Because of their partially overlapping substrate repertoires, it had been widely assumed that cysteine cathepsins other than cathepsin B might also contribute to trypsinogen activation in pancreatitis. Biochemical data obtained from bovine and human proteins revealed a specific cathepsin $\mathrm{L}$ cleavage site in trypsinogen at a position 3 amino acids C-terminal from the normal enteropeptidase/cathepsin B cleavage site (5). This cleavage prevents the generation of the N-terminal isoleucine that is essential for the active conformation of trypsin. Hence, in contrast to cathepsin B, cleavage of trypsinogen by cathepsin L results in an inactive trypsin variant. Active trypsin is not cleaved by cathepsin $\mathrm{L}$ at this position but at a second cathepsin $\mathrm{L}$ cleavage site between amino acids E82 and G83 that inactivates trypsin (5). These data imply that cathepsin $\mathrm{L}$ can prevent ectopic trypsinogen activation. In keeping with this notion, $\mathrm{Ctsl}^{-/-}$mice show increased intrapancreatic trypsin activity upon pancreatitis induction (5). Of note, $\mathrm{Ctsl}^{l^{-}-}$mice also show less severe pancreatitis, because, as a result of the less severe local and systemic inflammation, acinar cells undergo apoptosis instead of necrosis. Thus, cysteine cathepsins serve complex roles in the pancreas beyond activating and inactivating trypsinogen.

Cathepsins and protease zymogens: how do they meet? Despite compelling evidence for selective cleavage of trypsinogen by cathepsins B and L, an important cell biological question remains to be resolved: how can endolysosomal cathepsins meet trypsinogen, which is located in the secretory vesicles of the pancreatic acinar cell that are known as zymogen granules? Of note, colocalization of cathepsin B and trypsinogen has been shown by subcellular fractionation and immunogold labeling of EM sections in pancreata from patients and rodents with pancreatitis (reviewed in ref. 54).

The activation of trypsinogen begins in vesicular organelles that are acidic (55), raising the possibility that the colocalization of trypsinogen and cathepsins could result from the missorting of lysosomal cathepsins, due to inefficient trafficking from the trans-Golgi network to the endosomal/lysosomal compartment via the $\mathrm{m} 6 \mathrm{p} / \mathrm{m} 6 \mathrm{p}$ receptor pathway (56). It has been estimated that approximately $5 \%-10 \%$ of lysosomal proteins are missorted and enter the constitutive and regulated secretory pathways, and it is clear that cathepsin L and other cysteine cathepsins can selectively effect their protease function in secretory vesicles $(18,57)$. For example, cathepsin L has been identified as a major enzyme involved in the generation of secreted pituitary neuropeptides (e.g., enkephalin, ACTH, $\alpha$-MSH, $\beta$-endorphin) from their large 
Table 3

Involvement of cysteine cathepsins in organ diseases - evidence from human and animal studies

\begin{tabular}{|c|c|c|c|c|}
\hline Disease & Cysteine cathepsin & Evidence from humans & Evidence from mice & Refs. \\
\hline Atherosclerosis & $\mathrm{K}, \mathrm{L}$, and $\mathrm{S}$ & $\begin{array}{l}\text { Cathepsins are expressed in } \\
\text { macrophages, smooth muscle cells, } \\
\text { and endothelial cells } \\
\text { of atherosclerotic lesions. }\end{array}$ & $\begin{array}{l}\text { All three single knockout mice show } \\
\text { attenuated atherosclerosis in } \\
\text { backgrounds deficient for apoE } \\
\text { or LDL receptor. }\end{array}$ & $20,125-127$ \\
\hline $\begin{array}{l}\text { Cancer and } \\
\text { metastasis }\end{array}$ & $\begin{array}{l}\mathrm{B}, \mathrm{F}, \mathrm{H}, \mathrm{K}, \mathrm{L} \\
\mathrm{V}, \mathrm{S} \text {, and } \mathrm{X} / \mathrm{Z}\end{array}$ & $\begin{array}{l}\text { Cathepsins are overexpressed in many } \\
\text { carcinomas and frequently associated } \\
\text { with poor prognosis of patients. } \\
\text { Cathepsins execute multiple functions } \\
\text { in death, proliferation, and invasion } \\
\text { of human cancer cell lines. }{ }^{\mathrm{A}}\end{array}$ & $\begin{array}{l}\text { Studies of cathepsin-knockout mice } \\
\text { revealed that these proteases are } \\
\text { also involved in angiogenesis and } \\
\text { tumor-associated inflammation. }{ }^{\mathrm{A}}\end{array}$ & $19,128-133$ \\
\hline $\begin{array}{l}\text { Metabolic } \\
\text { syndrome } \\
\text { (obesity and } \\
\text { type II diabetes) }\end{array}$ & $\mathrm{K}, \mathrm{L}$, and $\mathrm{S}$ & $\begin{array}{l}\text { High serum CTSS has been } \\
\text { associated with type II diabetes. }\end{array}$ & $\begin{array}{l}\text { Muscle Ctsl expression is } \\
\text { increased in diabetes-prone mice; } \\
\text { deletions of Ctsl or Ctsk prevent } \\
\text { obesity and improve glucose metabolism. }\end{array}$ & $125,134-136$ \\
\hline Lung diseases & $\mathrm{B}, \mathrm{H}, \mathrm{K}, \mathrm{L}$, and $\mathrm{S}$ & $\begin{array}{c}\text { High levels of active cathepsins } \\
\text { were detected in inflammatory } \\
\text { bronchoalveolar lavage fluid in acute } \\
\text { and chronic inflammatory lung diseases. }\end{array}$ & $\begin{array}{l}\text { Ctsk in lung fibroblasts is involved in } \\
\text { matrix turnover and protects from } \\
\text { lung fibrosis. Ctsb mediates } \\
\text { inflammation of silica-treated } \\
\text { macrophages. Cysteine cathepsins } \\
\text { (i.e., Ctsh) are involved in surfactant } \\
\text { protein processing. }\end{array}$ & $127-141$ \\
\hline Immune defects & $C, L, V$, and $S$ & $\begin{array}{l}\text { CTSV is overexpressed in and } \\
\text { associated with early-onset myasthenia } \\
\text { gravis. CTSC deficiency (Papillon-Lefèvre/ } \\
\text { Haim-Munk syndrome) causes impaired } \\
\text { immune response against microbes } \\
\text { in the mouth. }\end{array}$ & $\begin{array}{l}\text { Cts/-null mice show impaired positive } \\
\text { selection of Th cells; however, Tregs } \\
\text { are not affected. This causes } \\
\text { resistance to autoimmune diabetes. } \\
\text { Ctss-null mice show impaired invariant } \\
\text { chain degradation in antigen-presenting cells, } \\
\text { causing resistance to the development of } \\
\text { experimental autoimmune collagen-induced } \\
\text { arthritis and myasthenia gravis. }\end{array}$ & $114,142-146$ \\
\hline $\begin{array}{l}\text { Rheumatoid } \\
\text { arthritis, } \\
\text { osteoarthritis }\end{array}$ & $B, L, K$, and $S$ & $\begin{array}{l}\text { In patients, the cathepsins are expressed } \\
\text { in joint cartilage and synovial cells as } \\
\text { well as in infiltrating immune cells. They } \\
\text { contribute to cartilage destruction } \\
\text { and immune response. }\end{array}$ & $\begin{array}{l}\text { Selective inhibition of cathepsins has } \\
\text { protective effects in some animal models, } \\
\text { while only minor or even counterproductive } \\
\text { effects have been observed for Ctsk } \\
\text { inhibition in other models. }\end{array}$ & $147-150$ \\
\hline
\end{tabular}

AIn these processes, cysteine cathepsins cooperate within their family and with other proteases such as matrix metalloproteinases and the uPAR system.

precursor proteins, such as preproenkephalin and proopiomelanocortin, in human cells and mice $(17,58,59)$. However, as it stands, it is not clear how the selective sorting of cathepsins into zymogen granules can be induced during the onset of acute pancreatitis.

In the search for alternative mechanisms, it was recently proposed that incompletely executed autophagy leads to the observed enzyme colocalization in early pancreatitis (60). Both starvation and pancreatitis induce an autophagic response in pancreatic acinar cells that engulfs cytoplasmic proteins and organelles, including zymogen granula (60). After fusion of autophagosomes with lysosomes, the contents of the resulting autophagolysosomes are digested by lysosomal hydrolases, including cathepsins (61). Eventually, the autophagolysosomes break down and disappear in starvation-induced autophagy. In contrast, during pancreatitis the autophagic process is impaired at the level of autophagolysosome degradation, thereby providing an acidic compartment for colocalization of trypsinogen and cathepsins (60). Furthermore, an imbalance consisting of low levels of cathepsin L, which degrades trypsinogen and trypsin, and high levels of cathepsin B, which activates trypsinogen, has been found in autophagic vesicles during pancreatitis (60). This, in turn, results in intracellular accumulation of active trypsin that activates further digestive enzymes, thereby causing damage to pancreatic cells, a hallmark event in the pathogenesis of pancreatitis.

\section{Cysteine cathepsins in the heart}

Cathepsin L: a homeostatic protease within the myocardium. Cardiomyopathies represent a heterogeneous group of heart diseases that are characterized by progressive myocardial remodeling, leading to impaired pump function of the heart $(62,63)$. Among many other etiologies, defects in lysosomes and lysosomal hydrolases have been shown to cause myocardial heart disease $(64,65)$. Cardiomyopathies have also been described as a component of inherited disorders caused by deficiency of lysosomal glycosidases; for example, Pompe disease is caused by abnormal accumulation of glycogen. Deficiency of lysosome-associated membrane protein 2 (LAMP-2) induces the accumulation of autophagic vacuoles and causes Danon disease, which is characterized by severe myopathy 


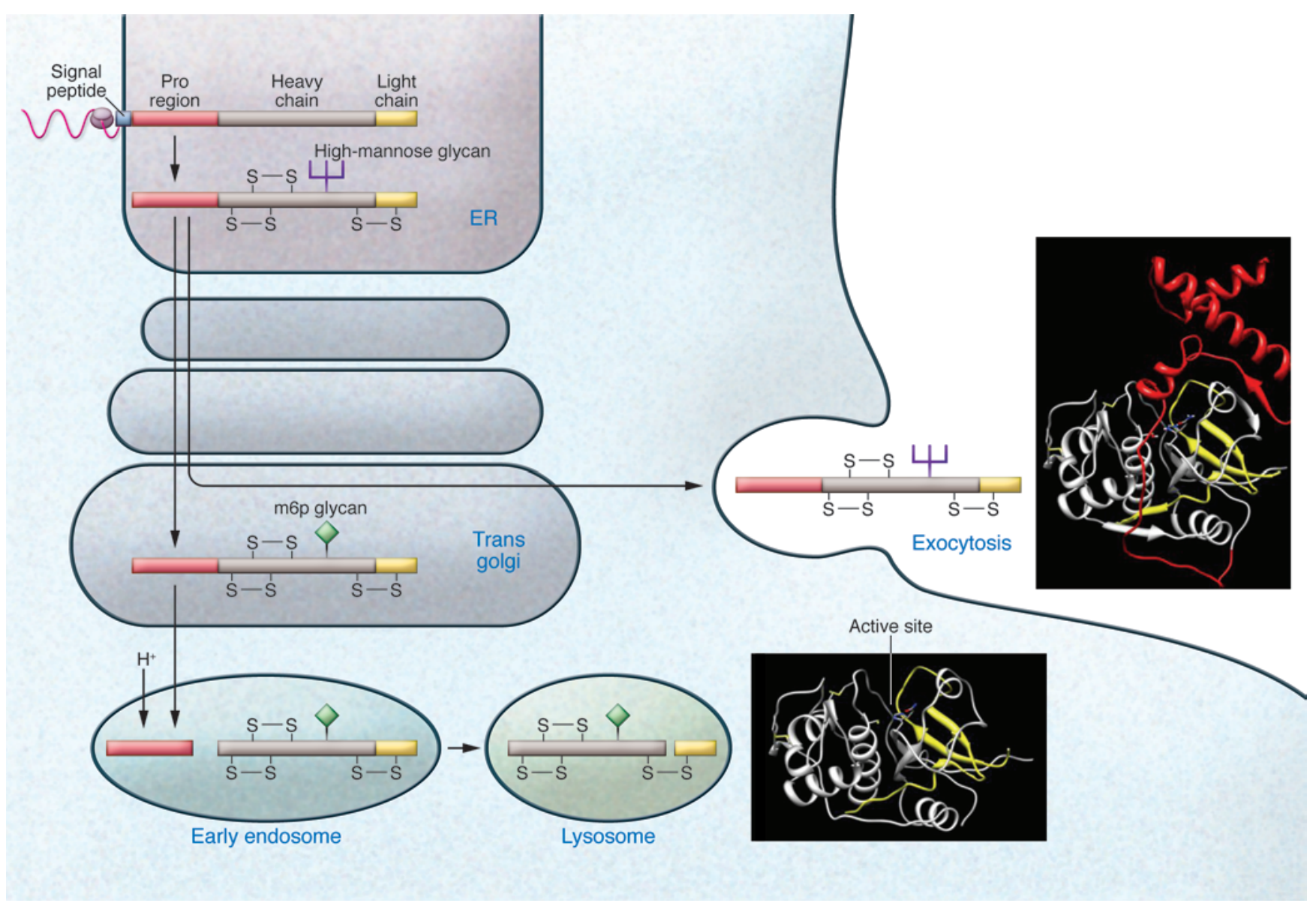

Figure 2

Cathepsin structures and traditional and nontraditional protease trafficking. Cathepsins contain a signal peptide (blue) that directs insertion of the nascent polypeptide chain into the ER. Within the ER, the signal peptide is cleaved and the protein folds with the assistance of the proregion (red). Disulfide bond formation (indicated by S-S) and N-linked glycosylation with high-mannose glycans subsequently occurs in the ER. Within the Golgi, mannose residues are phosphorylated to form m6p, which is used to route the protein into the endosomal/lysosomal compartment via the m6p receptor. Upon initial acidification of the endosome, cathepsins are activated, which leads to cleavage of the proregion and further activation of the cathepsin, resulting in further proteolytic processing in the lysosome into heavy and light chains (yellow). A portion of the cathepsins is not converted to the m6p form and as a result is shunted into the exocytosis pathway. Conversion to $\mathrm{m} 6 \mathrm{p}$ appears to be rate limiting, as overexpression of a given cathepsin greatly increases the proportion of the enzyme in this pathway. Ribbon diagrams depict the structure of mature cathepsin $\mathrm{L}$ in the extracellular matrix and in the lysosome. The ribbon colors correspond to the colors used in the diagram on the left.

of cardiac and skeletal muscles (64, 65). Of note, LAMP-2-deficient mice display a vacuolar cardioskeletal myopathy that is similar to that observed in individuals with Danon disease (66). Increased activity of lysosomal enzymes also has been found in patients with hypertensive heart failure $(67,68)$.

In contrast to those of these well-established lysosomal storage diseases and their causative molecules, the role of lysosomal proteases in the heart remained elusive for a long time. However, recent findings with 1 -year-old $\mathrm{Cts}^{-/-}$mice shed light on this issue $(69,70)$. These aging animals develop a cardiac phenotype that displays key features of human dilated cardiomyopathy (69). As such, complete deficiency of cathepsin L causes interstitial myocardial fibrosis and the appearance of pleomorphic nuclei in cardiomyocytes, both characteristics of human cardiomyopathies. It also causes cardiac chamber dilation and impaired cardiac contraction. Moreover, at 1 year of age, $\mathrm{Ctsl}^{-/-}$mice develop supraventricular tachycardia, ventricular extrasystoles, and first-degree atrioventricular blockage (69). Deficiency of cathepsin L in mice affects the endolysosomal system of cardiomyocytes in newborn mice (69). In particular, it increases the number of acidic organelles, although these vesicles lack the accumulation of typical lysosomal storage materials and have altered morphology (70). Subsequently, the defects in the acidic cellular compartment are accompanied by complex biochemical and cellular alterations, with loss of cytoskeletal proteins and mitochondrial impairment (70). These findings raise the question of how cathepsin L deficiency and the observed alteration of the acidic cellular compartment change intracellular signaling toward induction of a hypertrophic response with subsequent dilation of the heart.

Cathepsin L involvement in cardiac signal transduction. In a gainof-function approach, human cathepsin L was transgenically overexpressed in the cardiomyocytes of mice (71). The transgenic 
A

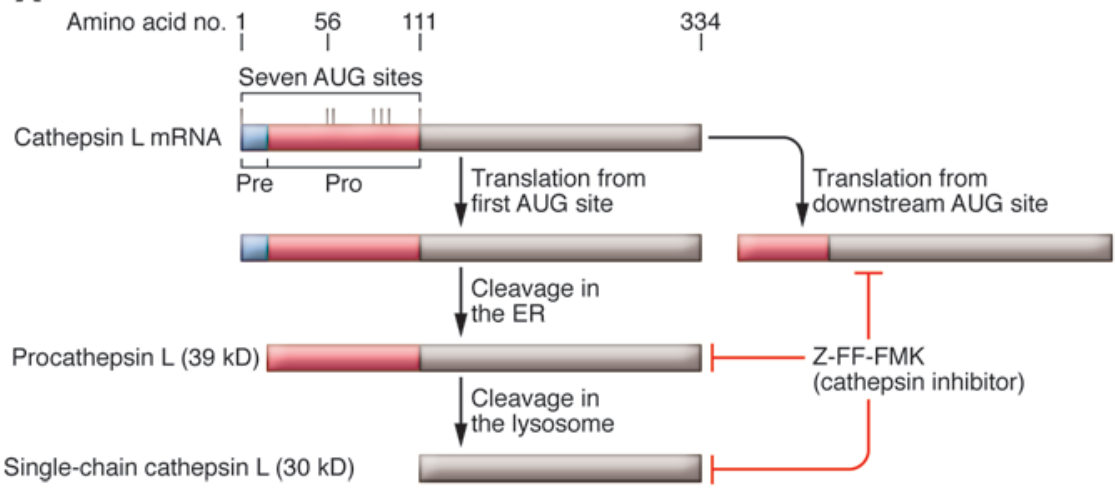

\section{Figure 3}

Alternative translation from downstream AUG sites produces cytoplasmic and nuclear cathepsin L. (A) Alternative translation from downstream AUG sites produces cathepsin $L$ that is devoid of the leader sequence and that can be present outside the lysosome, including in the cytosol and the nucleus. (B) Alternative translation leads to peptides that lack the leader sequence and thus are targeted to the cytosol or nucleus. The initial folding of the protein requires an intact proregion, and the mature protein is stabilized by three disulfide bonds. Thus, this process may require the presence of yet to be identified chaperones to generate a functional enzyme.

\section{B}

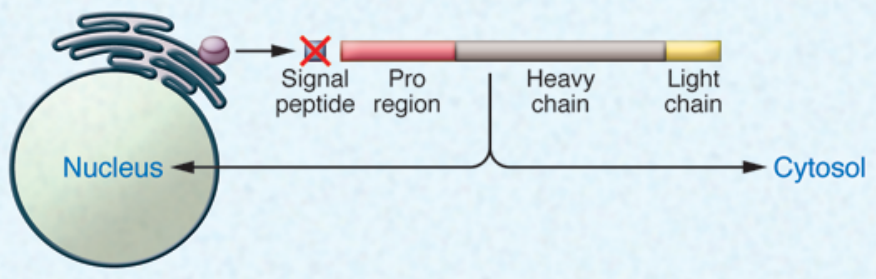

mice had a decreased hypertrophic response and exhibited reduced cardiomyocyte apoptosis in two models of hypertensive heart failure, i.e., aortic banding and angiotensin II infusion. The observed cardioprotective effect of human cathepsin L overexpression in the mouse heart was associated with inhibition of Akt signaling (71). As of yet, it has not been fully resolved how cathepsin L blocks Akt signaling in the heart, but some information on how cathepsin $\mathrm{L}$ affects intracellular signal transduction processes is available from data obtained in mouse epidermis. Cathepsin L-deficient mouse keratinocytes show enhanced recycling of nondegraded plasma membrane receptors and their ligands to the cell surface and sustained growth factor signaling (72). This impaired termination of growth factor signaling within the endolysosomal compartment results in increased Ras, Akt, and MAPK activation (73). As a consequence, the proliferation of basal epidermal keratinocytes is increased. This, in turn, results in the epidermal hyperproliferation and increased susceptibility to squamous carcinogenesis in the skin of $\mathrm{Ctsl}^{-/-}$mice (74). Thus, the overexpression of cathepsin $\mathrm{L}$ in the endolysosomal compartment of cardiomyocytes is likely to result in immediate proteolysis of endocytosed receptors and their ligands. Therefore, both the time span available for signaling from the receptors and the rate of receptor recycling are reduced. This premature signal termination lowers the activation state of cytosolic kinases like Akt and therefore reduces the hypertrophic response of the challenged mouse myocardium (71).

Extracellular cathepsins in cardiac remodeling and repair. It is also worth noting that dilative cardiomyopathy-associated interstitial fibrosis in $\mathrm{Ctsl}^{-/-}$mice is the only defect in the heart that cannot be rescued by transgenic reexpression of mouse cathepsin $\mathrm{L}$ in cardiomyocytes of otherwise cathepsin L-deficient mice (75). These results imply that the observed cardiac fibrosis in $\mathrm{Ctsl}^{-/-}$ mice is caused by the absence of cathepsin $\mathrm{L}$ from cardiac fibroblasts and not from cardiomyocytes. Since collagen I (Col1a1)
mRNA expression is not enhanced in cathepsin L-deficient myocardium, the accumulation of collagen in the ECM is most likely due to impaired collagen turnover.

Cathepsin L is mainly located in the endosomal/lysosomal compartment, but a fraction of the proenzyme can be secreted and activated by other proteases such as matrix metalloproteinases. Activated extracellular cathepsin $\mathrm{L}$ is capable of processing ECM proteins, such as fibronectin, laminin, and type I, IV, and XVIII collagen, even at neutral $\mathrm{pH}$ (76-78). Cysteine cathepsins, such as cathepsin S and cathepsin B, are highly abundant in the left ventricular myocardium of patients with hypertensive heart failure and therefore have been implicated in turnover of the ECM and cardiac remodeling in this disease $(68,79)$.

This turns attention to another emerging aspect of extracellular cathepsin L - its involvement in cardiac repair. Endothelial progenitor cells home to ischemic areas, differentiate, and build the basis for new blood vessels, a process known as neovascularization (80). Improvement of vascularization and function of ischemic areas in the heart may represent a physiologic function of endothelial progenitor cells. The infusion of excess numbers of in vitro-differentiated progenitors is currently being evaluated in clinical trials aimed at improving the outcome of postinfarction congestive heart failure (81). Bone marrow-derived endothelial progenitor cells show high cathepsin L expression and activity, and neovascularization after experimental hind limb ischemia is substantially impaired in $\mathrm{Cts}^{l^{-/}}$mice (82). Furthermore, infusion of cathepsin L-deficient mononuclear cells, but not that of mononuclear cells from cathepsin D- or MMP9deficient mice, results in a failure of these cells to home efficiently. Mechanistically, cathepsin L is required for the invasion and the proteolytic matrix-degrading activity of the endothelial progenitors (82). Interestingly, diabetes, a typical risk factor for ischemic heart disease, impairs human and mouse cathepsin L 


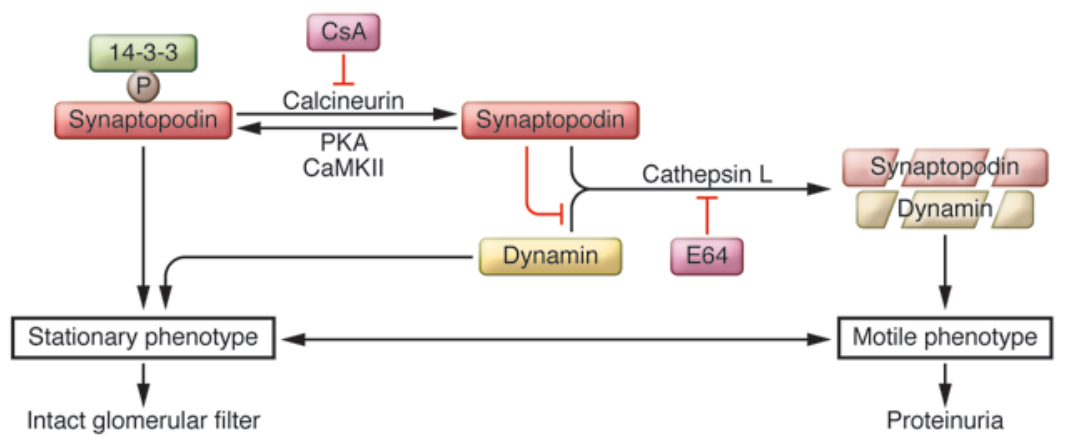

Figure 4

Cytosolic cathepsin $L$ and its function in proteinuric kidney disease. Phosphorylation of synaptopodin by PKA or CaMKII promotes 14-3-3 binding, which protects synaptopodin and dynamin against cathepsin L-mediated cleavage, thereby contributing to a stationary podocyte phenotype and an intact glomerular filtration barrier. Dephosphorylation of synaptopodin by calcineurin abrogates the interaction with 14-3-3. This renders the cathepsin L cleavage sites of synaptopodin accessible and promotes the degradation of synaptopodin and dynamin, thereby promoting a motile phenotype and the development of proteinuria. The calcineurin inhibitor CsA and the cathepsin inhibitor E64 safeguard against proteinuria by stabilizing synaptopodin and dynamin protein levels in podocytes.

activity (but not that of other major proteases) in endothelial progenitor cells and also reduces invasion of these cells in a glucose concentration-dependent manner (83). Hence, the specific impairment of cathepsin L function by hyperglycemia may explain the poor neovascularization and regeneration capacities of ischemic tissues in diabetic patients.

\section{The role of truncated forms of cathepsin $L$ in murine and human renal disease}

The role of podocyte cathepsin $L$ in proteinuric kidney diseases. The kidney glomerulus is a highly specialized structure that ensures the selective ultrafiltration of plasma, so that essential proteins are retained in the blood (84). Podocytes are unique cells with a complex cellular organization, consisting of a cell body, major processes, and foot processes (FPs). The FPs cover the outer aspect of the glomerular basement membrane. They form a characteristic interdigitating pattern with FPs of neighboring podocytes, leaving in between the filtration slits that are bridged by the glomerular slit diaphragm (SD) (84). Human genetic studies have revealed that mutations affecting several podocyte proteins, including $\alpha$-actinin-4 (85), nephrin (86), PLCE1 (87), podocin (88), transient receptor potential cation channel, subfamily C, member 6 (TRPC6) $(89,90)$, and inverted forming gene 2 (INF2) (91), lead to renal disease, owing to disruption of the filtration barrier and rearrangement of the podocyte actin cytoskeleton. Cell biologic and mouse genetic studies revealed that additional proteins regulate the plasticity of the podocyte actin cytoskeleton, such as Rho GDIa, podocalyxin, FAT tumor suppressor homolog 1 (FAT1), NCK adaptor protein 1 (Nck1), Nck2, synaptopodin, and dynamin, and are also of critical importance for sustained function of the kidney glomerular filtration barrier (reviewed in ref. 92).

The onset of proteinuria, induced by either LPS $(7,8)$ or puromycin aminonucleoside (PAN) (9), is associated with the induction of cathepsin L expression and activity in podocytes. The latter study also introduced the emerging concept that the onset of proteinuria represents a migratory event in podocyte FP that is associated by the activation of cathepsin L (9). This study also showed that the SD-associated CD2AP (93) was protected from puromycininduced degradation in primary podocyte cultures derived from $\mathrm{Cts}^{-/-}$mice (9). Subsequently, it was found that a cytoplasmic variant of cathepsin $\mathrm{L}$ in podocytes is required for the development of proteinuria in mice through a mechanism that involves the cleavage of the large GTPase dynamin (7) and synaptopodin (8). The clinical relevance of these findings was underscored by the observation that podocyte cathepsin L expression is increased in a variety of human proteinuric kidney diseases, ranging from minimal change disease (MCD) to diabetic nephropathy (7). Together, these results support the notion that cathepsin L-mediated proteolysis plays a critical role in the development of various forms of proteinuria (94).

Cathepsin L-mediated degradation of dynamin leads to proteinuria in mice. Dynamin is essential for the formation of clathrin-coated vesicles at the plasma membrane during endocytosis (95). Dynamin has also been implicated in the regulation of actin dynamics in certain cell types (96). Using the Prediction of Endopeptidase Proteolytic Sites computer algorithm (PEPS) for predicting putative cathepsin L substrates (46), dynamin was identified as a target of cathepsin L (7). In mouse podocytes, dynamin is cleaved by cytoplasmic cathepsin L during LPS- or PAN-induced experimental proteinuria, and gene delivery of cathepsin L-resistant dynamin protected mice against LPSinduced proteinuria (7). The notion that dynamin is required for proper podocyte structure and function is further supported by the observation that overexpression of dominant-negative dynamin leads to a loss of podocyte stress fibers in vitro and development of proteinuria in mice (7).

Cyclosporine A prevents proteinuria by blocking cathepsin $L-$ mediated degradation of synaptopodin in podocytes. Calcineurin is a ubiquitously expressed serine/threonine phosphatase (97). Its best-characterized function is the regulation of nuclear factor of activated $\mathrm{T}$ cells (NFAT) signaling. The immunosuppressive action of the calcineurin inhibitor cyclosporine A (CsA) stems from its inhibition of NFAT signaling in T cells (98). CsA can also induce remission of the proteinuria associated with diseases such as MCD and focal segmental glomerulosclerosis (FSGS) (99). Although T cell dysfunction is associated with some forms of proteinuria (100), including a subset of children with MCD (101), the salutary action of CsA in MCD and FSGS led to the suspicion that CsA might exert its effect, at least in part, independently of its effects on T cells, a hypothesis also supported by reports of CsA effectiveness in nonimmunological human (102) and experimental (103) Alport syndrome.

Recently, a mechanism was identified wherein CsA blocks calcineurin-mediated dephosphorylation of synaptopodin in mouse podocytes, thereby preserving the phosphorylation-dependent synaptopodin/14-3-3 $\beta$ interaction (8). This interaction, in turn, protects synaptopodin from cathepsin L-mediated degradation and preserves a stable filtration barrier. Moreover, inducible expression of dominant-active calcineurin in podocytes is suf- 


\section{science in medicine}

ficient to cause the degradation of synaptopodin and dynamin, thereby inducing proteinuria (8). These data describe a calcineu$\mathrm{rin} /$ cathepsin L signaling pathway in podocytes that contributes to the regulation of kidney filter function (Figure 4). In contrast to most other calcineurin-NFAT controlled signaling events $(97,98,104,105)$, the antiproteinuric effect of CsA stems, at least in part, from its inhibition of cathepsin L-mediated degradation of synaptopodin in podocytes (Figure 4 and ref. 8).

The emerging role of nuclear cathepsin L in polycystic kidney disease. Polycystic kidney disease (PKD) represents the most common genetic renal disease in the world. PKD is inherited as an autosomal dominant (ADPKD) or autosomal recessive (ARPKD) trait and characterized by progressive enlargement of renal cysts (106). Cux1 is a homeobox gene that represses the cyclin kinase inhibitors p21 and p27, and transgenic mice ectopically expressing Cux1 develop renal hyperplasia (107). A 246-amino acid deletion in Cux1 accelerates PKD progression in the cpk model of ARPKD (11), and the ensuing phenotype was explained by a missing cathepsin L cleavage site in the truncated Cux1 mutant, which thereby maintains increased tubular cell proliferation and apoptosis. Cux 1 is proteolytically processed by a nuclear isoform of cathepsin L (10). In both human ADPKD cells and in kidneys of mice with a targeted deletion in Pkd1, a murine model of PKD, decreased nuclear cathepsin L levels are associated with increased levels of Cux 1 protein in the cystic cells in vitro and the cysts in vivo (11). These results suggest a mechanism by which reduced Cux1 processing by nuclear cathepsin L results in the accumulation of Cux1, downregulation of $\mathrm{p} 21 / \mathrm{p} 27$, and increased cell proliferation in PKD (11). Furthermore, they provide proof of principle of the hypothesis that nuclear cathepsin $\mathrm{L}$ is capable of processing transcription factors that control important cellular programs, such as growth.

\section{Outlook}

Recent studies have uncovered multiple divergent roles for different cathepsins in a variety of physiologic and pathophysiologic processes. From the findings in the different organs discussed above, it has become clear that cathepsins serve as regulatory enzymes beyond acting as simple housekeeping proteases and harbor important functions outside the lysosome. Future studies are required to delineate the translational mechanisms leading to the generation of the truncated forms of cathepsin L. Structural insights should aid drug development of cathepsin inhibitors that act in an allosteric manner and, therefore, may be more specific for individual cathepsin forms than currently available inhibitors. The understanding of cathepsins and their recently identified substrates continues to be an expanding area in biology. Most importantly, they provide starting points for the development of novel selective therapeutic modalities for various human diseases.

\section{Acknowledgments}

This work was supported in part by a US NIH grant (DK073495) to J. Reiser, the American Society of Nephrology Carl W. Gottschalk Research Scholar grant to B.D. Adair, and the Deutsche Forschungsgemeinschaft SFB 850 Project B7, the Centre of Chronic Immunodeficiency Freiburg grant (TP8), the Excellence Initiative of the German Federal and State Governments (EXC 294), and the European Union Framework Program (FP7 "MICROENVIMET" no. 201279) to T. Reinheckel.

Address correspondence to: Jochen Reiser, Department of Medicine, University of Miami Miller School of Medicine, 1580 NW 10th Avenue, Batchelor Building, 6th Floor (R-762), Miami, Florida 33136, USA. Phone: 305.243.2349; Fax: 305.243.8321; E-mail: jreiser@med.miami.edu.
1. Puente XS, Sanchez LM, Overall CM, Lopez-Otin C. Human and mouse proteases: a comparative genomic approach. Nat Rev Genet. 2003;4(7):544-558.

2. Barrett AJ, Rawlings ND. 'Species' of peptidases. Biol Chem. 2007;388(11):1151-1157.

3. Willstätter R, Bamann E. Über die Proteasen der Magenschleimhaut. Erste Abhandlung über die Enzyme der Leukozyten. Hoppe-Seyler's Z Physiol Chem. 1929;180(1-3):127-143.

4. Rawlings ND, Morton FR, Kok CY, Kong J, Barrett AJ. MEROPS: the peptidase database. Nucleic Acids Res. 2008;36(Database issue):D320-D325.

5. Wartmann T, et al. Cathepsin L inactivates human trypsinogen, whereas cathepsin L-deletion reduces the severity of pancreatitis in mice. Gastroenterology. 2010;138(2):726-737.

6. Puri N, Roche PA. Mast cells possess distinct secretory granule subsets whose exocytosis is regulated by different SNARE isoforms. Proc Natl Acad Sci US A. 2008;105(7):2580-2585.

7. Sever S, et al. Proteolytic processing of dynamin by cytoplasmic cathepsin L is a mechanism for proteinuric kidney disease. J Clin Invest. 2007; 117(8):2095-2104.

8 . Faul C, et al. The actin cytoskeleton of kidney podocytes is a direct target of the antiproteinuric effect of cyclosporine A. Nat Med. 2008;14(9):931-938.

9. Reiser J, et al. Podocyte migration during nephrotic syndrome requires a coordinated interplay between cathepsin L and alpha3 integrin. J Biol Chem. 2004;279(33):34827-34832

10. Goulet B, et al. A cathepsin L isoform that is devoid of a signal peptide localizes to the nucleus in $S$ phase and processes the $\mathrm{CDP} / \mathrm{Cux}$ transcription factor. Mol Cell. 2004;14(2):207-219.
11. Alcalay NI, et al. Acceleration of polycystic kidney disease progression in cpk mice carrying a deletion in the homeodomain protein Cux1. Am J Physiol Renal Physiol. 2008;295(6):F1725-F1734.

12. Vasiljeva O, Reinheckel T, Peters C, Turk D, Turk $\mathrm{V}$, Turk B. Emerging roles of cysteine cathepsins in disease and their potential as drug targets. Curr Pharm Des. 2007;13(4):387-403.

13. Honey K, Rudensky AY. Lysosomal cysteine proteases regulate antigen presentation. Nat Rev Immunol. 2003;3(6):472-482.

14. Stoch SA, Wagner JA. Cathepsin K inhibitors: a novel target for osteoporosis therapy. Clin Pharmacol Ther. 2008;83(1):172-176.

15. Deal C. Potential new drug targets for osteoporosis. Nat Clin Pract Rheumatol. 2009;5(1):20-27.

16. Friedrichs B, et al. Thyroid functions of mouse cathepsins B, K, and L. J Clin Invest. 2003; 111(11):1733-1745.

17. Funkelstein L, et al. Major role of cathepsin L for producing the peptide hormones $\mathrm{ACTH}$, beta-endorphin, and alpha-MSH, illustrated by protease gene knockout and expression. $J$ Biol Chem. 2008;283(51):35652-35659.

18. Brix K, Dunkhorst A, Mayer K, Jordans S. Cysteine cathepsins: cellular roadmap to different functions. Biochimie. 2008;90(2):194-207.

19. Mohamed MM, Sloane BF. Cysteine cathepsins: multifunctional enzymes in cancer. Nat Rev Cancer. 2006;6(10):764-775.

20. Lutgens SP, Cleutjens KB, Daemen MJ, Heeneman $\mathrm{S}$. Cathepsin cysteine proteases in cardiovascular disease. FASEB J. 2007;21(12):3029-3041.

21. Abudula A, Rommerskirch W, Weber E, Gunther D, Wiederanders B. Splice variants of human cathep- sin L mRNA show different expression rates. Biol Chem. 2001;382(11):1583-1591.

22. Jean D, Guillaume N, Frade R. Characterization of human cathepsin L promoter and identification of binding sites for NF-Y, Sp1 and Sp3 that are essential for its activity. Biochem J. 2002; 361(pt 1):173-184.

23. Jean D, Rousselet N, Frade R. Cathepsin L expression is up-regulated by hypoxia in human melanoma cells: role of its $5^{\prime}$-untranslated region. Biochem J. 2008;413(1):125-134

24. Bulynko YA, Hsing LC, Mason RW, Tremethick DJ, Grigoryev SA. Cathepsin L stabilizes the histone modification landscape on the $\mathrm{Y}$ chromosome and pericentromeric heterochromatin. Mol Cell Biol. 2006;26(11):4172-4184.

25. Duncan EM, et al. Cathepsin L proteolytically processes histone $\mathrm{H} 3$ during mouse embryonic stem cell differentiation. Cell. 2008;135(2):284-294.

26. Zheng XL, Kitamoto Y, Sadler JE. Enteropeptidase, a type II transmembrane serine protease. Front Biosci (Elite Ed). 2009;1:242-249.

27. Carmona E, et al. Potency and selectivity of the cathepsin L propeptide as an inhibitor of cysteine proteases. Biochemistry. 1996;35(25):8149-8157.

28. Schilling K, et al. Selectivity of propeptide-enzyme interaction in cathepsin L-like cysteine proteases. Biol Chem. 2009;390(2):167-174.

29. Coulombe R, Grochulski P, Sivaraman J, Menard R, Mort JS, Cygler M. Structure of human procathep$\sin \mathrm{L}$ reveals the molecular basis of inhibition by the prosegment. EMBOJ. 1996;15(20):5492-5503.

30. Turk V, Turk B, Turk D. Lysosomal cysteine proteases: facts and opportunities. EMBO J. 2001;20(17):4629-4633. 
31. Quraishi O, et al. The occluding loop in cathepsin $\mathrm{B}$ defines the $\mathrm{pH}$ dependence of inhibition by its propeptide. Biochemistry. 1999;38(16):5017-5023.

32. LaLonde JM, et al. The crystal structure of human procathepsin K. Biochemistry. 1999;38(3):862-869.

33. Sivaraman J, Nagler DK, Zhang R, Menard R, Cygler M. Crystal structure of human procathep$\sin \mathrm{X}$ : a cysteine protease with the proregion covalently linked to the active site cysteine. J Mol Biol. 2000;295(4):939-951.

34. Kaulmann G, Palm GJ, Schilling K, Hilgenfeld R, Wiederanders B. The crystal structure of a Cys 25 -> Ala mutant of human procathepsin S elucidates enzyme-prosequence interactions. Protein Sci. 2006;15(11):2619-2629.

35. Tao K, Stearns NA, Dong J, Wu QL, Sahagian GG. The proregion of cathepsin $\mathrm{L}$ is required for proper folding, stability, and ER exit. Arch Biochem Biophys. 1994;311(1):19-27.

36. Vernet T, et al. Processing of the papain precursor The ionization state of a conserved amino acid motif within the Pro region participates in the regulation of intramolecular processing. J Biol Chem. 1995;270(18):10838-10846.

37. Kreusch S, et al. An evolutionarily conserved tripartite tryptophan motif stabilizes the prodomains of cathepsin L-like cysteine proteases. Eur J Biochem. 2000;267(10):2965-2972.

38. Schilling K, Pietschmann S, Fehn M, Wenz I, Wiederanders B. Folding incompetence of cathepsin L-like cysteine proteases may be compensated by the highly conserved, domain-building N-terminal extension of the proregion. Biol Chem. 2001; 382(5):859-865.

39. Baranski TJ, Faust PL, Kornfeld S. Generation of a lysosomal enzyme targeting signal in the secretory protein pepsinogen. Cell. 1990;63(2):281-291.

40. Braulke T, Bonifacino JS. Sorting of lysosomal proteins. Biochim Biophys Acta. 2009;1793(4):605-614.

41. Mach L, Mort JS, Glossl J. Noncovalent complexes between the lysosomal proteinase cathepsin B and its propeptide account for stable, extracellular, high molecular mass forms of the enzyme. J Biol Chem. 1994;269(17):13036-13040.

42. Menard R, et al. Autocatalytic processing of recombinant human procathepsin L. Contribution of both intermolecular and unimolecular events in the processing of procathepsin $\mathrm{L}$ in vitro. $J$ Biol Chem. 1998;273(8):4478-4484.

43. Jaiswal JK, Andrews NW, Simon SM. Membrane proximal lysosomes are the major vesicles responsible for calcium-dependent exocytosis in nonsecretory cells. J Cell Biol. 2002;159(4):625-635.

44. Reddy A, Caler EV, Andrews NW. Plasma membrane repair is mediated by $\mathrm{Ca}(2+)$-regulated exocytosis of lysosomes. Cell. 2001;106(2):157-169.

45. Muntener K, Zwicky R, Csucs G, Rohrer J, Baici A. Exon skipping of cathepsin B: mitochondrial targeting of a lysosomal peptidase provokes cell death. J Biol Chem. 2004;279(39):41012-41017.

46. Lohmuller T, et al. Toward computer-based cleavage site prediction of cysteine endopeptidases. Biol Chem. 2003;384(6):899-909.

47. Chiari H. Über die Selbstverdauung des menschlichen Pankreas. Zeitschrift für Heilkunde. 1896; 17:69-96.

48. Chen JM, Ferec C. Chronic pancreatitis: genetics and pathogenesis. Annu Rev Genomics Hum Genet. 2009;10:63-87.

49. Greenbaum LM, Hirshkowitz A, Shoichet I. The activation of trypsinogen by cathepsin B. J Biol Chem. 1959;234:2885-2890

50. Figarella C, Miszczuk-Jamska B, Barrett AJ. Possible lysosomal activation of pancreatic zymogens. Activation of both human trypsinogens by cathepsin B and spontaneous acid. Activation of human trypsinogen 1. Biol Chem Hoppe Seyler. 1988; 369 suppl:293-298
51. Bode W, Huber R. Induction of the bovine trypsinogen-trypsin transition by peptides sequentially similar to the N-terminus of trypsin. FEBS Lett. 1976;68(2):231-236.

52. Van Acker GJ, Saluja AK, Bhagat L, Singh VP, Song AM, Steer ML. Cathepsin B inhibition prevents trypsinogen activation and reduces pancreatitis severity. Am J Physiol Gastrointest Liver Physiol. 2002;283(3):G794-G800.

53. Halangk W, et al. Role of cathepsin B in intracellular trypsinogen activation and the onset of acute pancreatitis. J Clin Invest. 2000;106(6):773-781.

54. van Acker GJ, Perides G, Steer ML. Co-localization hypothesis: a mechanism for the intrapancreatic activation of digestive enzymes during the early phases of acute pancreatitis. World J Gastroenterol. 2006;12(13):1985-1990.

55. Lerch MM, Saluja AK, Runzi M, Dawra R, Steer ML. Luminal endocytosis and intracellular targeting by acinar cells during early biliary pancreatitis in the opossum. J Clin Invest. 1995;95(5):2222-2231.

56. Roshy S, Sloane BF, Moin K. Pericellular cathepsin $\mathrm{B}$ and malignant progression. Cancer Metastasis Rev. 2003;22(2-3):271-286.

57. Hook V, Funkelstein L, Lu D, Bark S, Wegrzyn J, Hwang SR. Proteases for processing proneuropeptides into peptide neurotransmitters and hormones. Annu Rev Pharmacol Toxicol. 2008;48:393-423.

58. Yasothornsrikul S, et al. Cathepsin L in secretory vesicles functions as a prohormone-processing enzyme for production of the enkephalin peptide neurotransmitter. Proc Natl Acad Sci U S A. 2003; 100(16):9590-9595

59. Hwang SR, et al. Cathepsin L expression is directed to secretory vesicles for enkephalin neuropeptide biosynthesis and secretion. J Biol Chem. 2007;282(13):9556-9563.

60. Mareninova OA, et al. Impaired autophagic flux mediates acinar cell vacuole formation and trypsinogen activation in rodent models of acute pancreatitis. J Clin Invest. 2009;119(11):3340-3355.

61. Ravikumar B, et al. Mammalian macroautophagy at a glance. J Cell Sci. 2009;122(pt 11):1707-1711.

62. Heineke J, Molkentin JD. Regulation of cardiac hypertrophy by intracellular signalling pathways. Nat Rev Mol Cell Biol. 2006;7(8):589-600.

63. Hill JA, Olson EN. Cardiac plasticity. N Engl J Med. 2008;358(13):1370-1380.

64. Nishino I, et al. Primary LAMP-2 deficiency causes $\mathrm{X}$-linked vacuolar cardiomyopathy and myopathy (Danon disease). Nature. 2000;406(6798):906-910.

65. Maron BJ, et al. Clinical outcome and phenotypic expression in LAMP2 cardiomyopathy. JAMA. 2009;301(12):1253-1259.

66. Tanaka Y, et al. Accumulation of autophagic vacuoles and cardiomyopathy in LAMP-2-deficient mice. Nature. 2000;406(6798):902-906

67. Akbar H, Cancelas J, Williams DA, Zheng J, Zheng $Y$. Rational design and applications of a Rac GTPase-specific small molecule inhibitor. Methods Enzymol. 2006;406:554-565.

68. Cheng XW, et al. Elastolytic cathepsin induction/ activation system exists in myocardium and is upregulated in hypertensive heart failure. Hypertension. 2006;48(5):979-987

69. Stypmann J, et al. Dilated cardiomyopathy in mice deficient for the lysosomal cysteine peptidase cathepsin L. Proc Natl Acad Sci U S A. 2002; 99(9):6234-6239

70. Petermann I, et al. Lysosomal, cytoskeletal, and metabolic alterations in cardiomyopathy of cathepsin L knockout mice. FASEB J. 2006;20(8):1266-1268.

71. Tang Q, et al. Lysosomal cysteine peptidase cathep$\sin \mathrm{L}$ protects against cardiac hypertrophy through blocking AKT/GSK3beta signaling. J Mol Med. 2009;87(3):249-260.

72. Reinheckel T, et al. The lysosomal cysteine protease cathepsin $\mathrm{L}$ regulates keratinocyte proliferation by control of growth factor recycling. $J$ Cell Sci. 2005;118(pt 15):3387-3395.

73. Dennemarker J, et al. Impaired turnover of autophagolysosomes in cathepsin L deficiency. Biol Chem. 2010;391(8):913-922.

74. Dennemarker J, et al. Deficiency for the cysteine protease cathepsin L promotes tumor progression in mouse epidermis. Oncogene. 2010; 29(11):1611-1621.

75. Spira D, et al. Cell type-specific functions of the lysosomal protease cathepsin $\mathrm{L}$ in the heart. J Biol Chem. 2007;282(51):37045-37052.

76. Everts V, et al. Osteoclastic bone degradation and the role of different cysteine proteinases and matrix metalloproteinases: differences between calvaria and long bone. J Bone Miner Res. 2006;21(9):1399-1408.

77. Felbor U, Dreier L, Bryant RA, Ploegh HL, Olsen $\mathrm{BR}$, Mothes W. Secreted cathepsin L generates endostatin from collagen XVIII. EMBO J. 2000; 19(6):1187-1194.

78. Maciewicz RA, Etherington DJ. A comparison of four cathepsins (B, L, N and S) with collagenolytic activity from rabbit spleen. Biochem J. 1988; 256(2):433-440.

79. Schenke-Layland K, et al. Cardiomyopathy is associated with structural remodelling of heart valve extracellular matrix. Eur Heart J. 2009; 30(18):2254-2265

80. Chavakis E, Urbich C, Dimmeler S. Homing and engraftment of progenitor cells: a prerequisite for cell therapy. J Mol Cell Cardiol. 2008;45(4):514-522.

81. Chavakis E, Koyanagi M, Dimmeler S. Enhancing the outcome of cell therapy for cardiac repair: progress from bench to bedside and back. Circulation. 2010;121(2):325-335

82. Urbich C, et al. Cathepsin $\mathrm{L}$ is required for endothelial progenitor cell-induced neovascularization. Nat Med. 2005;11(2):206-213.

83. Urbich C, Dernbach E, Rossig L, Zeiher AM, Dimmeler S. High glucose reduces cathepsin L activity and impairs invasion of circulating progenitor cells. J Mol Cell Cardiol. 2008;45(3):429-436.

84. Somlo S, Mundel P. Getting a foothold in nephrotic syndrome. Nat Genet. 2000;24(4):333-335.

85. Kaplan JM, et al. Mutations in ACTN4, encoding alpha-actinin-4, cause familial focal segmental glomerulosclerosis. Nat Genet. 2000;24(3):251-256.

86. Kestila M, et al. Positionally cloned gene for a novel glomerular protein--nephrin--is mutated in congenital nephrotic syndrome. Mol Cell. 1998;1(4):575-582.

87 . Hinkes B, et al. Positional cloning uncovers mutations in PLCE1 responsible for a nephrotic syndrome variant that may be reversible. Nat Genet. 2006;38(12):1397-1405

88. Boute N, et al. NPHS2, encoding the glomerular protein podocin, is mutated in autosomal recessive steroid-resistant nephrotic syndrome. Nat Genet. 2000;24(4):349-354.

89. Winn MP, et al. A mutation in the TRPC6 cation channel causes familial focal segmental glomerulosclerosis. Science. 2005;308(5729):1801-1804.

90. Reiser J, et al. TRPC6 is a glomerular slit diaphragm-associated channel required for normal renal function. Nat Genet. 2005;37(7):739-744.

91. Brown EJ, et al. Mutations in the formin gene INF2 cause focal segmental glomerulosclerosis. Nat Genet. 2010;42(1):72-76.

92. Mundel P, Reiser J. Proteinuria: an enzymatic disease of the podocyte? Kidney Int. 2010;77(7):571-580.

93. Shih NY, et al. Congenital nephrotic syndrome in mice lacking CD2-associated protein. Science. 1999;286(5438):312-315

94. Defilippi P, et al. p125FAK tyrosine phosphorylation and focal adhesion assembly: studies with phosphotyrosine phosphatase inhibitors. Exp Cell Res. 1995;221(1):141-152.

95. Kirchhausen T. Three ways to make a vesicle. Nat Rev Mol Cell Biol. 2000;1(3):187-198. 
96. Schafer DA. Regulating actin dynamics at membranes: a focus on dynamin. Traffic. 2004; 5(7):463-469.

97. Aramburu J, Heitman J, Crabtree GR. Calcineurin: a central controller of signalling in eukaryotes. EMBO Rep. 2004;5(4):343-348.

98. Crabtree GR, Olson EN. NFAT signaling: choreographing the social lives of cells. Cell. 2002; 109 suppl:S67-S79.

99. Meyrier A. Treatment of focal segmental glomerulosclerosis. Expert Opin Pharmacother. 2005; 6(9):1539-1549.

100. Shalhoub RJ. Pathogenesis of lipoid nephrosis: a disorder of T-cell function. Lancet. 1974; 2(7880):556-560

101.Audard V, et al. Minimal change nephrotic syndrome and classical Hodgkin's lymphoma: report of 21 cases and review of the literature. Kidney Int. 2006;69(12):2251-2260.

102. Charbit M, Gubler MC, Dechaux M, Gagnadoux MF, Grunfeld JP, Niaudet P. Cyclosporin therapy in patients with Alport syndrome. Pediatr Nephrol. 2007;22(1):57-63.

103. Chen D, et al. Cyclosporine a slows the progressive renal disease of alport syndrome (X-linked hereditary nephritis): results from a canine model. $J \mathrm{Am}$ Soc Nephrol. 2003;14(3):690-698.

104. Heit JJ, et al. Calcineurin/NFAT signalling regulates pancreatic beta-cell growth and function. Nature. 2006; 443(7109):345-349

105. Horsley V, Aliprantis AO, Polak L, Glimcher LH, Fuchs E. NFATc1 Balances Quiescence and Proliferation of Skin Stem Cells. Cell. 2008;132(2):299-310.

106. Igarashi P, Somlo S. Polycystic kidney disease. J Am Soc Nephrol. 2007;18(5):1371-1373.

107. Sansregret L, Nepveu A. The multiple roles of CUX1: insights from mouse models and cell-based assays. Gene. 2008;412(1-2):84-94.

108. McGrath ME. The lysosomal cysteine proteases. Annu Rev Biophys Biomol Struct. 1999;28:181-204.

109. Turk D, et al. Structure of human dipeptidyl peptidase I (cathepsin C): exclusion domain added to an endopeptidase framework creates the machine for activation of granular serine proteases. EMBOJ. 2001;20(23):6570-6582.

110. Erickson AH. Biosynthesis of lysosomal endopeptidases. J Cell Biochem. 1989;40(1):31-41.

111. Garnero P, et al. The collagenolytic activity of cathep$\sin \mathrm{K}$ is unique among mammalian proteinases. J Biol Chem. 1998;273(48):32347-32352.

112. Mason RW. Emerging functions of placental cathepsins. Placenta. 2008;29(5):385-390.

113. Bethel PA, et al. Design of selective Cathepsin inhibitors. Bioorg Med Chem Lett. 2009;19(16):4622-4625.

114.Viken MK, et al. Polymorphisms in the cathepsin L2 (CTSL2) gene show association with type 1 diabetes and early-onset myasthenia gravis. Hum Immunol. 2007;68(9):748-755

115.Zeeuwen PL, et al. Colocalization of cystatin $\mathrm{M} / \mathrm{E}$ and cathepsin $\mathrm{V}$ in lamellar granules and corneodesmosomes suggests a functional role in epidermal differentiation. I Invest Dermatol. 2007;127(1):120-128.

116. Haider AS, et al. Genomic analysis defines a cancerspecific gene expression signature for human squa- mous cell carcinoma and distinguishes malignant hyperproliferation from benign hyperplasia. JInvest Dermatol. 2006;126(4):869-881.

117. Hagemann S, et al. The human cysteine protease cathepsin $V$ can compensate for murine cathepsin $\mathrm{L}$ in mouse epidermis and hair follicles. Eur J Cell Biol. 2004;83(11-12):775-780.

118. Sevenich L, Pennacchio LA, Peters C, Reinheckel T. Human cathepsin $L$ rescues the neurodegeneration and lethality in cathepsin B/L double-deficient mice. Biol Chem. 2006;387(7):885-891.

119. Toomes C, et al. Loss-of-function mutations in the cathepsin $\mathrm{C}$ gene result in periodontal disease and palmoplantar keratosis. Nat Genet. 1999;23(4):421-424.

120.Pham CT, Ley TJ. Dipeptidyl peptidase I is required for the processing and activation of granzymes A and B in vivo. Proc Natl Acad Sci U S A. 1999;96(15):8627-8632.

121. Saftig P, et al. Impaired osteoclastic bone resorption leads to osteopetrosis in cathepsin-K-deficient mice. Proc Natl Acad Sci U S A. 1998;95(23):13453-13458.

122. Gowen M, et al. Cathepsin K knockout mice develop osteopetrosis due to a deficit in matrix degradation but not demineralization.J Bone Miner Res. 1999;14(10):1654-1663.

123.Gelb BD, Shi GP, Chapman HA, Desnick RJ. Pycnodysostosis, a lysosomal disease caused by cathepsin K deficiency. Science. 1996;273(5279):1236-1238.

124.Potts W, et al. Cathepsin L-deficient mice exhibit abnormal skin and bone development and show increased resistance to osteoporosis following ovariectomy. Int J Exp Pathol. 2004;85(2):85-96.

125. Kitamoto $\mathrm{S}$, et al. Cathepsin L deficiency reduces diet-induced atherosclerosis in low-density lipoprotein receptor-knockout mice. Circulation. 2007; 115(15):2065-2075.

126.Lutgens E, et al. Disruption of the cathepsin K gene reduces atherosclerosis progression and induces plaque fibrosis but accelerates macrophage foam cell formation. Circulation. 2006;113(1):98-107.

127. Sukhova GK, et al. Deficiency of cathepsin S reduces atherosclerosis in LDL receptor-deficient mice. J Clin Invest. 2003;111(6):897-906.

128. Gocheva V, et al. Distinct roles for cysteine cathepsin genes in multistage tumorigenesis. Genes Dev. 2006;20(5):543-556.

129.Vasiljeva O, et al. Tumor cell-derived and macrophage-derived cathepsin B promotes progression and lung metastasis of mammary cancer. Cancer Res. 2006;66(10):5242-5250.

130.Gondi CS, et al. Adenovirus-mediated expression of antisense urokinase plasminogen activator receptor and antisense cathepsin B inhibits tumor growth, invasion, and angiogenesis in gliomas. Cancer Res. 2004;64(12):4069-4077.

131.Tummalapalli $\mathrm{P}$, et al. RNAi-mediated abrogation of cathepsin B and MMP-9 gene expression in a malignant meningioma cell line leads to decreased tumor growth, invasion and angiogenesis. Int $J$ Oncol. 2007;31(5):1039-1050.

132. Sevenich L, et al. Synergistic antitumor effects of combined cathepsin B and cathepsin $Z$ deficiencies on breast cancer progression and metastasis in mice. Proc Natl Acad Sci U S A. 2010;107(6):2497-2502.

133. Gocheva $V$, et al. IL-4 induces cathepsin protease activity in tumor-associated macrophages to promote cancer growth and invasion. Genes Dev. 2010; 24(3):241-255.

134. Maehr R, et al. Cathepsin L is essential for onset of autoimmune diabetes in NOD mice.JClin Invest. 2005; 115(10):2934-2943.

135. Yang $M$, et al. Deficiency and inhibition of cathep$\sin \mathrm{K}$ reduce body weight gain and increase glucose metabolism in mice. Arterioscler Thromb Vasc Biol. 2008; 28(12):2202-2208.

136. Huang X, Vaag A, Carlsson E, Hansson M, Ahren B, Groop L. Impaired cathepsin L gene expression in skeletal muscle is associated with type 2 diabetes. Diabetes. 2003;52(9):2411-2418.

137. Perdereau C, Godat E, Maurel MC, Hazouard E, Diot E, Lalmanach G. Cysteine cathepsins in human silicotic bronchoalveolar lavage fluids. Biochim Biophys Acta. 2006;1762(3):351-356.

138. Hornung V, et al. Silica crystals and aluminum salts activate the NALP3 inflammasome through phagosomal destabilization. Nat Immunol. 2008; $9(8): 847-856$.

139. Srivastava $M$, et al. Overexpression of cathepsin $\mathrm{K}$ in mice decreases collagen deposition and lung resistance in response to bleomycin-induced pulmonary fibrosis. Respir Res. 2008;9:54.

140. Buhling F, et al. Pivotal role of cathepsin K in lung fibrosis. Am J Pathol. 2004;164(6):2203-2216.

141.Guttentag S, Robinson L, Zhang P, Brasch F, Buhling F, Beers M. Cysteine protease activity is required for surfactant protein $\mathrm{B}$ processing and lamellar body genesis. Am J Respir Cell Mol Biol. 2003;28(1):69-79.

142. Honey K, et al. Thymocyte expression of cathepsin L is essential for NKT cell development. Nat Immunol. 2002;3(11):1069-1074.

143.Hsieh CS, deRoos P, Honey K, Beers C, Rudensky AY. A role for cathepsin $\mathrm{L}$ and cathepsin $\mathrm{S}$ in peptide generation for MHC class II presentation. Jimmunol. 2002;168(6):2618-2625.

144. Nakagawa T, et al. Cathepsin L: critical role in Ii degradation and CD4 $\mathrm{T}$ cell selection in the thymus. Science. 1998;280(5362):450-453.

145. Nakagawa TY, et al. Impaired invariant chain degradation and antigen presentation and diminished collagen-induced arthritis in cathepsin S null mice. Immunity. 1999;10(2):207-217.

146. Tolosa $\mathrm{E}$, et al. Cathepsin V is involved in the degradation of invariant chain in human thymus and is overexpressed in myasthenia gravis. J Clin Invest. 2003;112(4):517-526.

147. Dejica VM, et al. Cleavage of type II collagen by cathepsin $\mathrm{K}$ in human osteoarthritic cartilage. Am J Pathol. 2008;173(1):161-169.

148. Schurigt U, et al. Cathepsin K deficiency partially inhibits, but does not prevent, bone destruction in human tumor necrosis factor-transgenic mice. Arthritis Rheum. 2008;58(2):422-434.

149. Svelander L, et al. Inhibition of cathepsin $\mathrm{K}$ reduces bone erosion, cartilage degradation and inflammation evoked by collagen-induced arthritis in mice. Eur J Pharmacol. 2009;613(1-3):155-162.

150.Asagiri M, et al. Cathepsin K-dependent toll-like receptor 9 signaling revealed in experimental arthritis. Science. 2008;319(5863):624-627. 